\title{
Is There any Association Between Nesfatin-1 and Generalized Anxiety Disorder?
}

\author{
Bulent Bahceci', Erman Bagcioglu² ${ }^{2}$ Aziz Ramazan Dilek³ ${ }^{3}$ Fatmagul Helvaci Celik , Ilkay Bahceci ${ }^{5}$, \\ Yucel Gonul ${ }^{6}$, Cicek Hocaoglu ${ }^{7}$
}

ÖZET:

Nesfatin-1 ve yaygın anksiyete bozukluğu arasında ilişki var mı?

\begin{abstract}
Amaç: Bu çalışmanın amacı yaygın anksiyete bozukluğu (YAB)'nun patogenezinde nesfatin-1'in olası rolünü araştırmaktır.
\end{abstract}

Yöntem: Bu çalışmada 40 YAB'lu hasta ile yaş ve BMI ile eşleştirilmiş 42 sağlıklı kontrol'un plasma nesfatin-1 düzeyleri ölçüldü. Anksiyete şiddeti Hamilton Anksiyete Derecelendirme Ölçeği (HAM-A) ile değerlendirildi.

Bulgular: Hasta ve kontrol grupları arasında nesfatin-1 düzeyinde anlamlı bir farklılık yoktur. Ortalama serum nesfatin-1 düzeyi yaş, hastalık süresi, BMI ve HAM-A skoru ile korelasyon göstermiyordu.

Sonuç: Sonuçlarımız YAB'nun nesfatin-1 ile ilişkili olduğunu desteklemiyor.

Anahtar sözcükler: yaygın anksiyete bozukluğu, nesfatin-1, vücut kitle indeksi

Klinik Psikofarmakoloji Bulteni 2014;24(1):55-8

\section{ABSTRACT:}

Is there any association between nesfatin-1 and generalized anxiety disorder?

Objective: The aim of the present study was to find out the possible role of nesfatin-1 in the pathogenesis of generalized anxiety disorder (GAD).

Methods: In this study, we measured plasma nesfatin-1 levels in $40 \mathrm{GAD}$ patients and 42 controls that were matched by age and BMI. The severity of anxiety was evaluated with the Hamilton Anxiety Rating Scale (HAM-A).

Results: There was no statistically significant difference in the nesfatin-1 levels between patient and control groups. The mean serum nesfatin-1 level did not show any correlation with age, duration of illness, BMI, HAM-A scores in the patient and control groups.

Conclusion: Our results do not support that nesfatin-1 is associated with GAD.

Keywords: generalized anxiety disorder, nesfatin-1, body mass index

Bulletin of Clinical Psychopharmacology 2014;24(1):55-8
${ }^{1}$ Assist. Prof., ${ }^{4} \mathrm{MD},{ }^{7}$ Assoc. Prof., Recep Tayyip Erdogan University School of Medicine, Department of Psychiatry, Rize - Turkey

${ }^{2}$ Assist. Prof., Afyon Kocatepe University School of Medicine, Department of Psychiatry, Afyonkarahisar - Turkey ${ }^{3}$ Assist. Prof., ${ }^{5} \mathrm{MD}$, Recep Tayyip Erdogan University, School of Medicine,

Department of Microbiology, Rize - Turkey

${ }^{6} \mathrm{PhD}$., Afyon Kocatepe University School of Medicine, Department of Anatomy, Afyonkarahisar - Turkey

Address reprint requests to: Yrd. Doç. Dr. Erman Bağcioğlu, Afyon Kocatepe Üniversitesi, Tıp Fakültesi, Ruh Sağlığı ve Hastalıkları Anabilim Dali, Afyonkarahisar - Turkey

E-mail address:

ermanbagcioglu@yahoo.com

Date of submission:

February 19, 2013

Date of acceptance:

April 21, 2013

\section{Declaration of interest:}

B.B., E.B., A.R.D., F.H.C., I.B., Y.G., C.H.: The authors reported no conflict of interest related to this article.

\section{INTRODUCTION}

Generalized anxiety disorder (GAD) is characterized by persistent fear or worries. Individuals often feel that something bad is just about to happen ${ }^{1}$. There is strong evidence for a neurobiological contribution to GAD. Some neurotransmitters have been indicated as possible contributors in the pathogenesis of GAD, including gamma-aminobutyric acid (GABA)/ benzodiazepine complexes ${ }^{2,3}$, serotonin and norepinephrine $\mathrm{e}^{4-7}$ and cholecystokinin ${ }^{8}$.

Nesfatin- 1 was discovered in 2006 by Oh-I et al. ${ }^{9}$ as an 82 amino acid polypeptide derived from the calcium and DNA-binding protein. Initially, nesfatin-1 emerged as the anorexigenic hormone that suppresses appetite ${ }^{10,11}$. Merali et al. ${ }^{12}$ have reported that nesfatin-1 may be involved in the mediation of anxiety and/or related responses. Since its discovery nesfatin-1 has been investigated in many psychiatric illnesses. Nesfatin-1 levels have been found to be altered in patients with depression ${ }^{13}$, panic disorder ${ }^{14}$, obsessive compulsive disorder ${ }^{15}$ and suicide victims ${ }^{16}$. GAD patients have presented with significantly lower plasma levels of nesfatin-1 than controls ${ }^{17}$. Further confirmatory research on nesfatin-1 is required to clarify its pathophysiological role in psychiatric illnesses, including GAD. 
Therefore, the objectives of this study were: (i) to find out the possible role of nesfatin-1 in the pathogenesis of GAD (ii) to determine the association of HAM-A scores, BMI and nesfatin-1 level in GAD patients and controls.

\section{METHODS}

\section{Participants}

A total of 40 patients (aged between 18 and 60 years) suffering from GAD were consecutively admitted to the psychiatry outpatient services of the University of Rize Recep Tayyip Erdogan. The diagnosis was made by two independent psychiatrists according to DSM-IV criteria. Patients were on their first psychiatric admission due to GAD. Patients with a different Axis I diagnosis, concomitant medical or neurological illness, substance abuse and psychotropic medication history were not included in this study. For the assessment of disease severity, the Turkish version of the Hamilton anxiety rating scale (HAM-A) was applied ${ }^{18}$. The control group consisted of 42 healthy individuals matched by age, sex, and BMI. Control subjects with any DSM IV diagnosis were excluded. These were free of any medication for at least 30 days prior to blood sampling. They had no history of endocrinological, hepatic, renal, or neurological disease. The BMI was calculated as body weight $(\mathrm{kg})$ divided by the square of the height $\left(\mathrm{m}^{2}\right)$ $\left(\mathrm{kg} / \mathrm{m}^{2}\right)$. Written informed consent was obtained from all subjects after a detailed and extensive description of the study. The study was approved by the local ethics committee.

\section{Biochemical Analysis}

Venous blood samples were taken from the subjects between 8:00 and 9:00 a.m. after overnight fasting. The samples were immediately centrifuged and stored at $-20^{\circ} \mathrm{C}$ for further analysis.

Serum nesfatin was measured by using an ELISA (enzyme-linked immunosorbent assay) test kit (Nesfatin-1 (1-82) (Human) Phoenix Pharmaceuticals, Burlingame, CA) according to the manufacturer's protocol. Absorbance (OD) of each well was measured at $450 \mathrm{~nm}$ with a microtiter plate reader (Multiskan GO, Thermo Scientific) within 10 minutes. Standard curves were fitted using Titri ELISA software. The fitted curve was then used to convert sample absorbance readings to nesfatin concentrations.

\section{Statistical Analysis}

Statistical analysis was performed using the statistical package for social sciences (SPSS). Student's t test, the Mann-Whitney U test and the chi-square test were used to compare variables between groups. Correlation analysis was performed by Kendall's tau-b correlation test. Results were considered significant at $\mathrm{p}<0.05$.

\section{RESULTS}

Of the 82 participants in the study, 40 were patients with GAD and 42 were controls. There were no significant differences between the patients and controls on demographic or clinical variables, including mean age, sex, marital status,

Table 1: Demographic and clinical variables of the patients and controls

\begin{tabular}{|c|c|c|c|}
\hline & $\begin{array}{c}\text { GAD }(n=40) \\
\text { Mean } \pm S D\end{array}$ & $\begin{array}{c}\text { Controls }(n=42) \\
\text { Mean } \pm \text { SD }\end{array}$ & $\mathbf{p}$ \\
\hline Age years & $34.8 \pm 8.6$ & $34.7 \pm 11.1$ & 0.97 \\
\hline Gender (male/female) & $6 / 34^{*}$ & $14 / 28$ & 0.05 \\
\hline Education (years) & $8.6 \pm 2.4$ & $11.8 \pm 2.1$ & $<0.001$ \\
\hline Marital status (single/married) & $17 / 23^{*}$ & $11 / 31$ & 0.12 \\
\hline $\mathrm{BMI}\left(\mathrm{kg} / \mathrm{m}^{2}\right)$ & $21.8 \pm 1.8$ & $21.0 \pm 1.7$ & 0.16 \\
\hline HAM-A & $25.7 \pm 2.8$ & NA & \\
\hline Duration of illness (years) & $1.8 \pm 0.88$ & NA & \\
\hline Fasting blood glucose (mg/dl) & $82.8 \pm 7.7$ & $80.6 \pm 5.7$ & 0.15 \\
\hline Nesfatin-1 (ng/ml) & $1.1 \pm 0.4$ (range: $0.7-2.6$ ) & $1.1 \pm 0.5$ (range: $0.8-3.2$ ) & 0.17 \\
\hline
\end{tabular}


Table 2: Correlation coefficients ( $r$ ) between nesfatin-1 level and other parameters in the patient and control groups

\begin{tabular}{lcccc} 
& $\begin{array}{c}\text { GAD }(\mathbf{n}=\mathbf{4 0}) \\
\text { Nesfatin-1 }\end{array}$ & $\mathbf{p}$ & $\begin{array}{c}\text { Controls }(\mathbf{n}=\mathbf{4 4}) \\
\text { Nesfatin-1 }\end{array}$ & $\mathbf{p}$ \\
\hline Age (years) & 0.15 & 0.32 & -0.06 & 0.68 \\
BMl & -0.09 & 0.57 & 0.06 & 0.70 \\
HAM-A & -0.02 & 0.86 & - & 0.33 \\
Fasting blood glucose (mg/dl) & -0.02 & 0.87 & -0.15 &
\end{tabular}

GAD: Generalized anaxiety disorder, BMI: Body Mass Index, HAM-A: Hamilton Anxiety Rating Scale

and BMI. However, the control group was more educated than the patient group $(\mathrm{p}<0.001)$. The details are presented in Table1. Mean plasma nesfatin-1 levels did not differ significantly between patients with GAD $(1.1 \pm 0.4 \mathrm{ng} / \mathrm{ml})$ and healthy control $(1.1 \pm 0.5 \mathrm{ng} / \mathrm{ml})$ subjects $(\mathrm{p}=0.17)$. The mean serum nesfatin-1 level did not show any correlation with age, BMI, HAM-A scores or fasting plasma glucose in patients (Table 2).

\section{DISCUSSION}

In this study, we found no significant alteration in nesfatin-1 plasma concentrations between healthy controls and GAD patients, a finding which is contrary to a previous report by Gunay et al. ${ }^{17}$, who reported decreased nesfatin-1 levels in GAD patients. The sample size in both studies was similar. However, differences in patient characteristics may account for this discrepancy. We recruited patients who were on their first psychiatric admission due to GAD, had no comorbid depression and no psychotropic drug use history.

Pre-clinical studies have provided supportive evidence that nesfatin-1 is involved in the pathogenesis of depression and anxiety ${ }^{19,20}$. Nesfatin-1 is observed in stress-related area such as the locus coeruleus and raphe nucleus ${ }^{21}$. Yoshido $\mathrm{N}$ et al. $^{22}$ have reported that nesfatin-1 stimulates stress-sensitive serotonergic neurons of the raphe nuclei and noradrenergic locus coeruleus neurons. Supporting the crucial role of nesfatin- 1 as a stressresponsive agent, intracerebroventricular nesfatin-1 injection in rats induces elevations of the stress hormones adrenocorticotropic hormone $(\mathrm{ACTH})$ and corticosterone in plasma ${ }^{23}$. Studies on humans support the animal model findings. Nesfatin-1 levels have been found to be higher in patients with major depressive disorder ${ }^{13}$, panic disorder ${ }^{14}$, and obsessive compulsive disorder ${ }^{15}$ than their respective control groups. Taken together, these results suggest that nesfatin-1 levels might be associated with anxiety and depression. However, our data fail to support the assumption that nesfatin-1 may be causally involved in the pathogenesis of GAD. Future studies with larger sample sizes are needed to clarify whether nesfatin-1 is involved in GAD. A number of studies have found that there is a negative correlation between plasma nesfatin-1 levels and $\mathrm{BMI}^{24,25}$. On the other hand, a positive association between nesfatin-1 and BMI has been noted by some authors ${ }^{13,26}$. We found no correlation between blood nesfatin-1 levels and the BMI. Different variables, including gender, mean age and medical characteristics of patients, may account for the discrepancy.

Several limitations should be taken into consideration when interpreting our results. First, the sample size was small. Second, due to the cross-sectional design, nesfatin-1 levels were only assessed once. To better understand the relationship between nesfatin-1 and GAD, followup of the course of nesfatin-1 levels is required.

\section{CONCLUSION}

According to our knowledge, this is the second study evaluating the plasma nesfatin-1 level in patients with GAD. Our results do not support that nesfatin- 1 is associated with GAD. Further studies with larger sample sizes and follow ups are needed to clarify the involvement of nesfatin-1 in GAD. 


\section{References:}

1. American Psychiatric Association. Diagnostic and statistical manual of mental disorders, ( $4^{\text {th }}$ ed, text revision). Washington, D:American Psychiatric Association, 2000.

2. Connor KM, Davidson JR. Generalized anxiety disorder: neurobiological and pharmacotherapeutic perspectives. Biol Psychiatry 1998;44(12):1286-94. [CrossRef]

3. Korpi ER, Grunder G, Luddens H. Drug interactions at GABA (A) receptors. Prog Neurobiol 2002;67(2):113-59. [CrossRef]

4. Strawn JR, Wehry AM, Delbello MP, Rynn MA, Strakowski S. Establishing the neurobiologic basis of treatment in children and adolescents with generalized anxiety disorder. Depress Anxiety 2012;29(4):328-39. [CrossRef]

5. Lohoff FW, Aquino TD, Narasimhan S, Multani PK, Etemad B, Rickels K. Serotonin receptor 2A (HTR2A) gene polymorphism predicts treatment response to venlafaxine $\mathrm{XR}$ in generalized anxiety disorder. Pharmacogenomics J 2013;13(1):21-6. [CrossRef]

6. Iny LJ, Pecknold J, Suranyi-Cadotte BE, Bernier B, Luthe L, Nair NP, et al. Studies of a neurochemical link between depression, anxiety, and stress from $(3 \mathrm{H})$ imipramine and $(3$ $\mathrm{H})$ paroxetine binding on human plateletes. Biol Psychiatry 1994;36(5):281-91. [CrossRef]

7. Garvey MJ, Noyes R Jr, Woodman C, Laukes C. The association of urinary 5-hydroxyindoleacetic acid and vanillylmandelic acid in patients with generalized anxiety. Neuropsychobiolgy 1995;31(1):6-9. [CrossRef]

8. Brawman-Mintzer O, Lydiard RB, Bradwejn J, Villarreal G, Knapp R, Emmanuel N, et al. Effects of the cholecystokinin agonist pentagastrin in patients with generalized anxiety disorder. Am j Psychiatry 1997;154(5):700-2.

9. Oh-I S, Shimizu H, Satoh T, Okada S, Adachi S, Inoue K, et al. Identification of nesfatin-1 as a satiety molecule in the hypothalamus. Nature 2006;443(7112):709-12. [CrossRef]

10. Palasz A, Krzystanek M, Worthington J, Czajkowska B, Kostro $\mathrm{K}$, Wiaderkiewicz et al. Nesfatin-1, a unique regulatory neuropeptide of the brain. Neuropeptides 2012;46(3):10512. [CrossRef]

11. Price TO,Samson WK, Niehoff ML, Banks WA. Permeability of the blood-brain barrier to a novel satiety molecule nesfatin-1. Peptides 2007;28(12):2372-81. [CrossRef]

12. Merali Z, Cayer C, Kent P, Anisman H. Nesfatin-1 increases anxiety and fear related behaviors in the rat. Psychopharmacology (Berl) 2008;201(1):115-23. [CrossRef]

13. Ari M, Ozturk OH, Bez Y, Oktar S, Erduran D. High plasma nesfatin-1 level in patients with major depressive disorder. Prog Neuropsychopharmacol Biol Psychiatry 2011;35(2):497500. [CrossRef]

14. Bez Y, Ari M, Ozturk OH, Oktar S, Can Y, Sadık S. Plasma nesfatin-1 level may be associated with disease severity in patients with panic disorder. Klinik Psikofarmakoloji BulteniBulletin of Clinical Psychopharmacology 2010;20(4):288-92. (Turkish)
15. Bez Y, Ari M, Ozturk OH, Oktar S, Can Y. Increased plasma nesfatin-1 levels in patients with obsessive compulsive disorder. Klinik Psikofarmakoloji Bulteni-Bulletin of Clinical Psychopharmacology 2012;22(1):5-9. (Turkish)

16. Bloem B, Xu L, Morava E, Faludi G, Palkovits M, Roubos EW, et al. Sex-specific differences in the dynamics of cocaineand amphetamine-regulated transcript and nesfatin-1 expressions in the midbrain of depressed suicide victims vs. controls. Neuropharmacology 2012;62(1):297-303. [CrossRef]

17. Gunay H, Tutuncu R, Aydin S, Dag E, Abasli D. Decreased plasma nesfatin-1 levels in patients with generalized anxiety disorder. Psychoneuroendocrinology 2012;37(12):1949-53. [CrossRef]

18. Yazıcı MK, Demir B, Tanrıverdi N, Karaagaoglu E, Yolac P. Hamilton Anxiety Rating Scale: interrater reliabilty and validity study. Turk Psikiyatri Derg 1998;9(2):114-17. (Turkish)

19. Goebel-Stengel M, Wang L, Stengel A, Tache Y. Localization of nesfatin-1 neurons in the mose brain and functional implication. Brain Res 2011;1396:20-34. [CrossRef]

20. Foo KS, Brismar H, Broberger C. Distribution and neuropeptide coexistence of nucleobindin-2 mRNA/ nesfatin-like immunoreactivity in the rat CNS. Neuroscience 2008;156(3):563-79. [CrossRef]

21. Brailoiu GC, Dun SL, Brailoiu E, Inan S, Yang J, Chang JK, et al. Nesfatin-1: distribution and interaction with a $G$ protein-coupled receptor in the rat brain. Endocrinology 2007;148(10):5088-94. [CrossRef]

22. Yoshido N, Maejima Y, Sedbazar U, Ando A, Kurita H, Damdindorj B, et al. Stressor-responsive central nesfatin-1 activates corticotropin-releasing hormone, noradrenaline and serotonin neurons and evokes hypothalamic-pituitaryadrenal axis. Aging (Albany NK) 2010;2(11):775-84

23. Konczol K, Bodnar I, Zelena D, Pinter O, Papp RS, Palkovits M, et al. Nesfatin-1/ NUCB2 may participate in the activation of the hypothalamic-pituitary-adrenal axis in rats. Neurochem Int 2010;57(3):189-97. [CrossRef]

24. Aydin S, Dag E, Ozkan Y, Erman F, Dagli AF, Kilic N, et al. Nesfatin-1 and ghrelin levels in serum and saliva of epileptic patients: hormonal changes can have a major effect on seizure disorders. Mol Cell Biochem 2009;328(1-2):49-56. [CrossRef]

25. Tsuchiya T, Shimizu H, Yamada M,Osaki A, Oh-I S, Ariyama $\mathrm{Y}$, et al. Fasting concentrations of nesfatin-1 are negatively correlated with body mass index in non-obese males. Clin Endocrinol (Oxf) 2010;73(4):484-90.

26. Saldanha JF, Carrero JJ, Lobo JC, Stockler-Pinto MB, Leal VO, Calixto A, et al. The newly identified anorexigenic adipokine nesfatin-1 in hemodialysis patients: are there associations with food intake, body composition and inflammation? Regul Pept 2012;173(1-3):82-5. [CrossRef] 